\title{
Eploring the World by Reading the Isotope Language
}

\author{
Walter Kutschera ${ }^{1}$ \\ VERA Laboratory, Faculty of Physics -Isotope Research, University of Vienna \\ Waehringerstr. 17, A-1090 Vienna, Austria \\ E-mail: walter.kutschera@univie.ac.at
}

It is well established that isotopic abundances are subject to small variations (mass fractionations) in essentially all physical and chemical processes. These variations - no matter how slight - can be traced with ever growing precision in natural and artificial materials. They thus constitute a way to follow processes in our environment at large. If radioisotopes are involved, temporal evolution of processes can be traced as well. The enormous progress of mass spectrometric techniques in both low-energy mass spectrometry (MS) and accelerator mass spectrometry (AMS) allow us to 'read' the isotope language in ever more detail in almost any terrestrial and extraterrestrial matter. In this review, a few examples of the application of stable isotopes of light elements ( $\mathrm{H}, \mathrm{C}, \mathrm{N}, \mathrm{O}$ ) and of some heavy ones $(\mathrm{Sr}, \mathrm{Pb})$, measured by MS, are described. Two unusual applications for the measurement of long-lived radioisotopes with AMS are also presented: The use of the ${ }^{14} \mathrm{C}$ bomb peak for dating retrospectively human DNA, and the search for superheavy elements in nature.

XLVIII International Winter Meeting on Nuclear Physics - BORMIO2010

Bormio, Italy

January 25-29 2010

\footnotetext{
$1 \quad$ Speaker
} 


\section{Introduction}

Isotopes were first recognized as a unique property of matter some hundred years ago [1, 2]. Frederick Soddy received the Nobel Prize in Chemistry 1921 for the concept of isotopes, which essentially stated that "certain elements exist in two or more forms which have different atomic weights but which are indistinguishable chemically". It is interesting to note that the neutron as a constituent of the atomic nucleus was unknown at the time and was discovered much later [3]. Nevertheless, isotopes were found for many elements, chiefly with the mass spectrograph developed by Francis Aston (Nobel Prize in Chemistry 1922) and others. It was also found that the abundances of rare stable isotopes are seldom below the permil level within an element.

As the precision of measuring isotopic abundances improved, it was noticed that they are subject to small variations (usually called 'mass fractionation') in essentially all physical and chemical processes. These variations can now be traced with ever growing precision in natural and man-made materials. They thus constitute a way to follow processes in our entire environment encompassing the atmosphere, the hydrosphere, the biosphere, the cryosphere, the lithosphere, the cosmosphere, and the technosphere [4]. If radioisotopes are involved, temporal evolution of processes can be traced as well. The enormous progress of mass spectrometric techniques in both low-energy mass spectrometry (MS) chiefly used for high-precision stable isotope analysis, and accelerator mass spectrometry (AMS) used for long-lived radioisotopes, allows one to decipher the 'isotope language' written into terrestrial and extraterrestrial matter. This contribution will try to convey the great power of gaining information about many fields by reading the isotope language. A few important examples for the application of stable isotopes will be given (e.g. connected to climate change), but emphasis will be placed on applications of AMS covering examples from diverse fields such as archaeology, geophysics, biochemistry, and astrophysics.

\section{Stable Isotopes}

Mass fractionation effects are more pronounced in isotopes of light elements than in heavy ones, because the relative mass difference between isotopes is larger. Some of the most important light elements on Earth are hydrogen, carbon, nitrogen, and oxygen. The isotopic abundances for these elements are given in Table 1 . Their stable isotopic abundances vary by at most four orders of magnitude. For comparison, the ultra-low isotopic abundance of the wellknown radioisotope ${ }^{14} \mathrm{C}$ is also given in the table. It is not possible to measure this most important cosmogenic radioisotope by MS because of interfering background. Only the greatly enhanced selectivity of AMS made this possible. Light stable isotopes are being traced in many of the domains mentioned above, and provide a wealth of information. For example the fractionation of hydrogen and oxygen isotopes in water $\left(\mathrm{H}_{2} \mathrm{O}\right)$ can be used to measure the origin and temperature of water sources. It is easy to understand that in phase transitions (e.g. evaporation of water) the lighter isotopes are preferred in the gas phase over the heavier ones. 
Thus, every phase transition induces such changes. In addition, the amount of fractionation also depends on the temperature. The lower the temperature the larger the fractionation effects. For chemical reactions one cannot predict a priori whether the lighter or heavier isotopes are preferred.

Table 1. Isotopic abundance of some light elements

\begin{tabular}{llr} 
Element & Isotope & Abundance (\%) \\
& & \\
\hline \multirow{2}{*}{ Hydrogen } & ${ }^{1} \mathrm{H}$ & 99.985 \\
& ${ }^{2} \mathrm{H}(\mathrm{D})$ & 0.015 \\
Carbon & ${ }^{12} \mathrm{C}$ & 98.900 \\
& ${ }^{13} \mathrm{C}$ & 1.100 \\
& ${ }^{14} \mathrm{C}$ & $0.00000000012 \quad\left(\mathrm{t}_{1 / 2}=5730 \mathrm{a}\right)$ \\
Nitrogen & ${ }^{14} \mathrm{~N}$ & 99.634 \\
& ${ }^{15} \mathrm{~N}$ & 0.366 \\
Oxygen & ${ }^{16} \mathrm{O}$ & 99.762 \\
& ${ }^{17} \mathrm{O}$ & 0.038 \\
& ${ }^{18} \mathrm{O}$ & 0.200 \\
\hline
\end{tabular}

The results of mass fractionation measurements are usually reported in the delta $(\delta)$ notation. This means that the ratio of a heavier to a lighter isotope is measured relative to this ratio in an isotopic standard material. The deviations are reported in units of \%o $\left(10^{-3}\right)$. Recently the precision of MS measurements are sometimes pushed into the $\varepsilon\left(10^{-4}\right)$ or even ppm $\left(10^{-6}\right)$ range. It is then possible to trace fractionation effects of heavier isotopes as well [5, 6]. For light isotopes the following conventions for $\delta$ values exist:

$$
\begin{array}{ll}
\delta \mathrm{D}=\left(\mathrm{D} / \mathrm{H}_{\text {sample }}-\mathrm{D} / \mathrm{H}_{\mathrm{SMOW}}\right) / \mathrm{D} / \mathrm{H}_{\mathrm{SMOW}} & \text { SMOW = Standard Mean Ocean Water } \\
\delta^{13} \mathrm{C}=\left({ }^{13} \mathrm{C} /{ }^{12} \mathrm{C}_{\text {sample }}-{ }^{13} \mathrm{C} /{ }^{12} \mathrm{C}_{\mathrm{PDB}}\right) /{ }^{13} \mathrm{C} /{ }^{12} \mathrm{C}_{\mathrm{PDB}} & \mathrm{PDB}=\text { PeeDee Belemnite carbonate standard } \\
\delta^{15} \mathrm{~N}=\left({ }^{15} \mathrm{~N} /{ }^{14} \mathrm{~N}_{\text {sample }}-{ }^{15} \mathrm{~N} /{ }^{14} \mathrm{~N}_{\mathrm{AIR}}\right) /{ }^{15} \mathrm{~N} /{ }^{14} \mathrm{~N}_{\text {AIR }} & \text { AIR = Nitrogen ratio in the atmosphere } \\
\delta^{18} \mathrm{O}=\left({ }^{18} \mathrm{O} /{ }^{16} \mathrm{O}_{\text {sample }}-{ }^{18} \mathrm{O} /{ }^{16} \mathrm{O}_{\text {SMOW }}\right) /{ }^{18} \mathrm{O} /{ }^{16} \mathrm{O}_{\text {SMOW }}
\end{array}
$$

In the following sections, examples for the use of $\delta^{13} \mathrm{C}$ and $\delta^{15} \mathrm{~N}$ for paleodiet studies, and $\delta^{18} \mathrm{O}$ as a paleothermometer in ice cores will be discussed.

\subsection{Paleodiet}

It is well known that in the photosynthesis of plants $\mathrm{CO}_{2}$ from the atmosphere is used to built cellulose and other compounds containing carbon. In this biochemical process, carbon isotopes from the $\mathrm{CO}_{2}$ are fractionated (the lighter ones react more readily). As it happens, there are two groups of plants which fractionate the carbon isotopes differently. Starting with a $\delta^{13} \mathrm{C}$ of $-7 \%$ in the $\mathrm{CO}_{2}$, so called $\mathrm{C} 3$ plants (e.g. rice, wheat, barley, potatoes) produce carbon 
compounds with $\delta^{13} \mathrm{C}$ of $-25 \%$ and $\mathrm{C} 4$ plants (e.g. sugar cane, maize, papyrus) form carbon compounds with $\delta^{13} \mathrm{C}$ of $-10 \%$. Humans who feed on wheat or on maize take up different carbon isotope ratios, which is reflected in their bone collagen. For example, it was possible to see the influence of Inkas (maize eaters) on the Chachapoya tribe in Peru being mainly C3 plants eaters by measuring $\delta^{13} \mathrm{C}$ in the bone collagene of Chachapoya mummies [7]. If combined with ${ }^{14} \mathrm{C}$ dating, even the time period of this influence can be determined. Another interesting signature is the fractionation of nitrogen isotopes. As it happens, the $\delta^{15} \mathrm{~N}$ value increases by $+3 \%$ o with every step (trophic level) in a feeding chain [8]. Here the heavy isotope of nitrogen reacts more readily. It is thus possible to study the dietary preference (carnivorous or herbivorous) of ancient humans by measuring $\delta^{15} \mathrm{~N}$ in collagen [9].

\subsection{Paleotemperature}

With the ongoing debate about global warming, the study of temperature changes in the past are of great interest [10]. Both $\delta \mathrm{D}$ and $\delta^{18} \mathrm{O}$ values in ice cores from Greenland [11] and Antarctica $[12,13]$ offer particularly valuable records to trace temperature changes back through the ice ages.

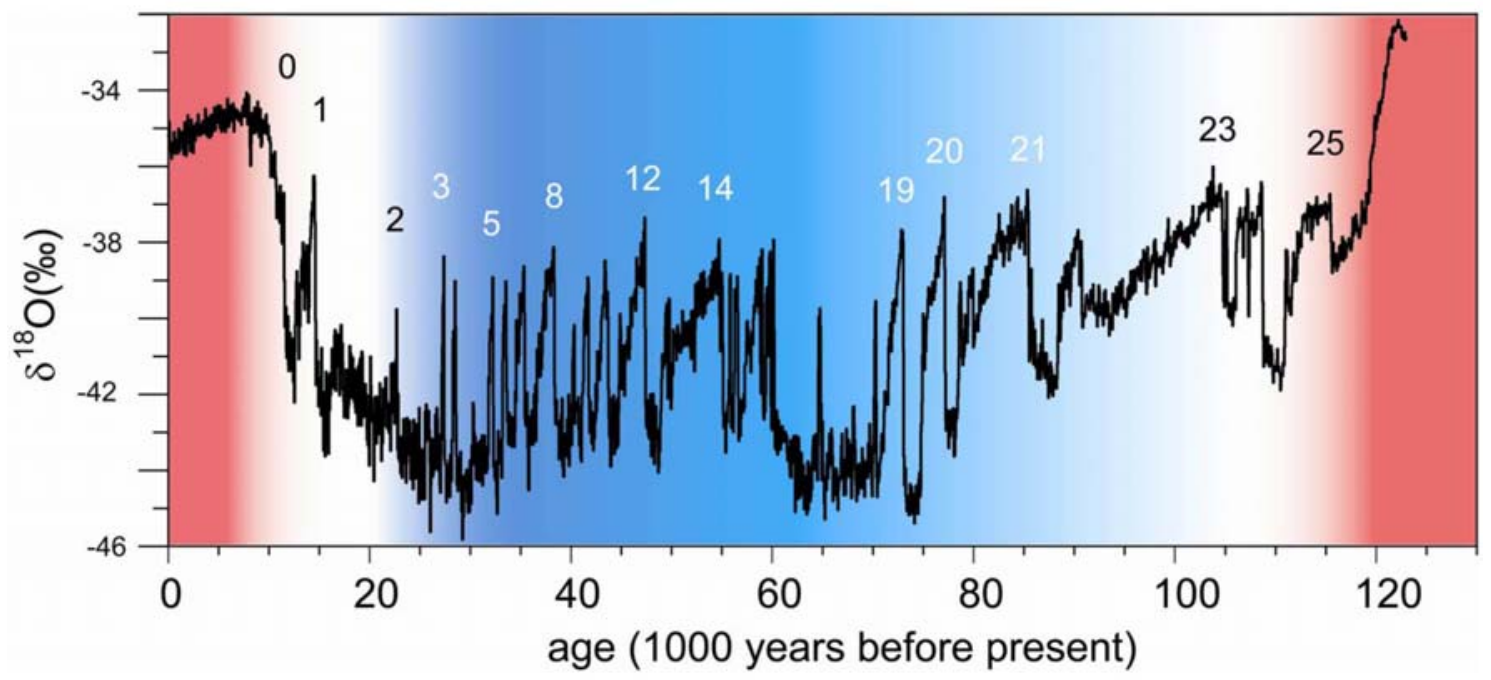

Fig. 1. Temperature record of the last 120,000 years as measured by the $\delta^{18} \mathrm{O}$ values in the NGRIP ice core from Greenland [11]. The figure indicates warmer (red) and colder (blue) period, with the abrupt temperature changes numbered by the Daansgard-Oeschger events (courtesy of Th. Stocker, University of Bern)

Fig. 1 shows the high-resolution isotope-temperature record from Greenland for the last 120,000 years. During the long cold period between the present warm period (Holocene) and the previous warm period (Eemian), one observes rapid temperature changes by up to $10{ }^{\circ} \mathrm{C}$. The origin of these so called Daansgard-Oeschger events are largely unknown, one is only sure that there were not caused by human impact. 


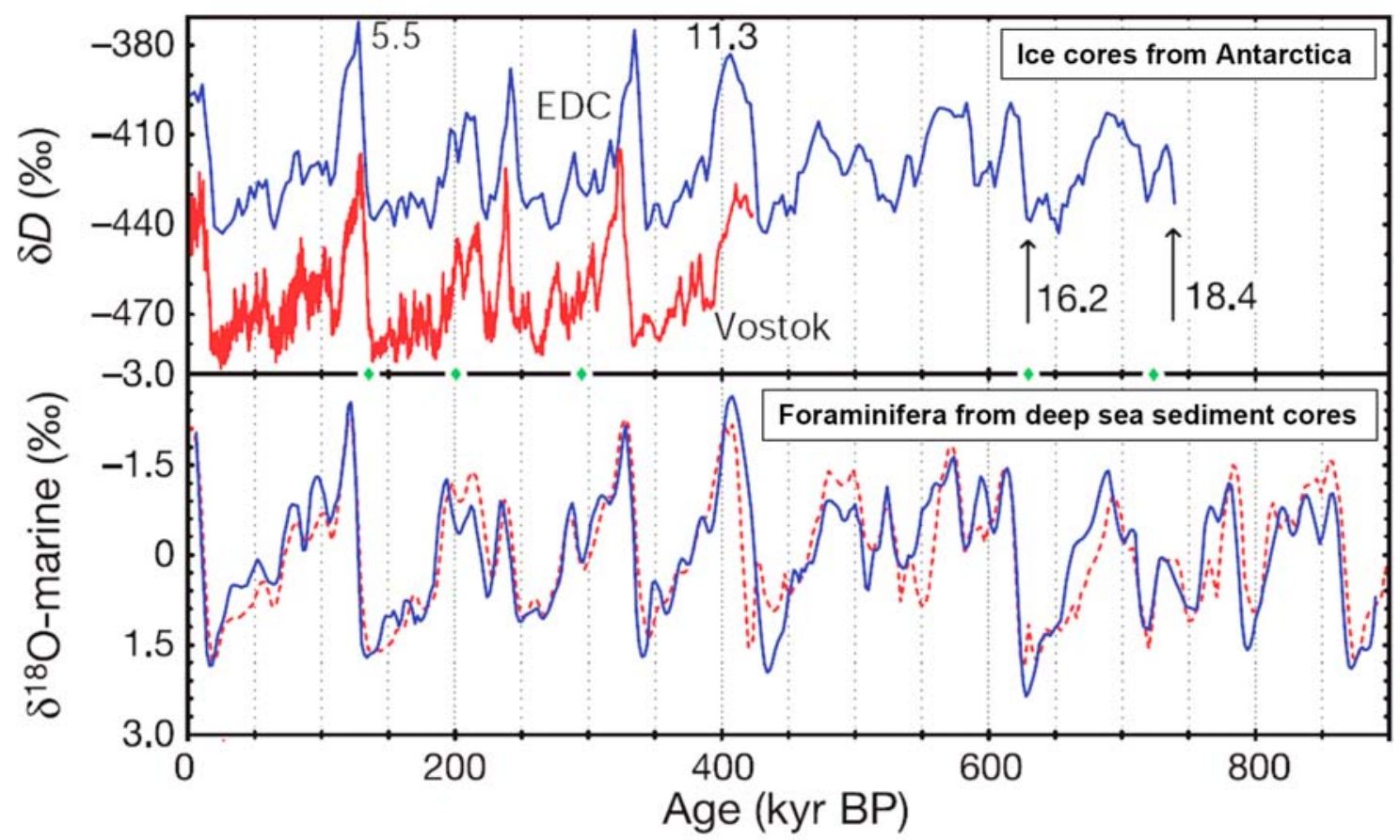

Fig. 2. Comparison of the $\delta D$ isotope-temperature record from ice cores in Antarctica $[12,13]$ with the $\delta^{18} \mathrm{O}$ isotope record from marine sediments [14], throughout the last 800,000 years.

In fig. 2 the longest isotope-temperature record in ice is compared with the oxygen isotope record in planktonic foraminifera shells from deep sea sediment cores which reflect the isotopic signature of ocean water [14]. As the land-locked ice volume increases during glacial periods, the ocean water becomes isotopically enriched in heavier isotopes. One can see this in the marine $\delta^{18} \mathrm{O}$ record of fig.2, since the $\delta^{18} \mathrm{O}$ values increase during glacial times. The effect is distinct but small, since only a few percent of the ocean water is transferred into land-locked ice sheets. The coming and going of ice ages is reasonably well explained by the astronomical theory of Milankovic [15], which calculates the insulation of the sun as a function of changing orbital parameters including the excentricity of the Earth's orbit ( 100,000 year period), the tilt of the Earth's axis $(\sim 41,000)$, and its precision $(\sim 23,000)$. Many papers discuss this important theory [16, 17]. A well readable description can also be found in Scientific American [18].

\subsection{The origin and migration of the Iceman “Ötzi”}

In 1991, a frozen body was discovered accidentally by mountain hikers at the border between Italy and Austria in the Ötztal Alp. The top of the male body, quickly nicknamed "Ötzi”, surfaced form a shallow, ice-filled depression at a high-altitude pass (Tisenjoch, $3120 \mathrm{~m}$ a.s.l.). The age of the body was determined by ${ }^{14} \mathrm{C}$ dating of bone and tissue samples from Ötzi at the AMS facilities of Oxford [19] and Zürich [20]. It turned out that Ötzi had lived somewhere between 5300 and 5050 years ago [21]. In an extensive study using various isotopes (Table 2) the origin of the Iceman was determined [22]. For this study small samples ( $\mu \mathrm{g}$ to $\mathrm{mg}$ ) from teeth and bones of the iceman were taken, and isotope ratios of ${ }^{18} \mathrm{O} /{ }^{16} \mathrm{O},{ }^{87} \mathrm{Sr} /{ }^{86} \mathrm{Sr}$, and ${ }^{206} \mathrm{~Pb} /{ }^{204} \mathrm{~Pb}$ were measured. 
Table 2. Isotopes used to study the Iceman Ötzi

\begin{tabular}{lllclll}
\hline Isotope & $\begin{array}{l}\text { Half-life } \\
\text { (years) }\end{array}$ & Source & $\begin{array}{c}\text { Measured } \\
\text { isotope ratio }\end{array}$ & Range & $\begin{array}{c}\text { Mass Spec } \\
\text { method }\end{array}$ & Information \\
\hline${ }^{14} \mathrm{C}$ & $5.7 \times 10^{3}$ & ${ }^{14} \mathrm{~N}(\mathrm{n}, \mathrm{p}){ }^{14} \mathrm{C}$ & ${ }^{14} \mathrm{C} /{ }^{12} \mathrm{C}$ & $10^{-15}-10^{-12}$ & AMS $^{\text {a }}$ & biolog. age \\
${ }^{87} \mathrm{Rb}$ & $4.9 \times 10^{10}$ & ${ }^{87} \mathrm{Rb} \rightarrow{ }^{87} \mathrm{Sr}$ & ${ }^{87} \mathrm{Sr} /{ }^{86} \mathrm{Sr}$ & $0.725-0.750$ & TIMS $^{\mathrm{b}}$ & soil origin \\
${ }^{238} \mathrm{U}$ & $4.5 \times 10^{9}$ & ${ }^{238} \mathrm{U} \rightarrow{ }^{206} \mathrm{~Pb}$ & ${ }^{206} \mathrm{~Pb} /{ }^{204} \mathrm{~Pb}$ & $18.25-19.50$ & MC-ICPMS $^{\mathrm{c}}$ & soil origin \\
${ }^{40} \mathrm{~K}$ & $1.3 \times 10^{9}$ & ${ }^{40} \mathrm{~K} \rightarrow{ }^{40} \mathrm{Ar}$ & ${ }^{40} \mathrm{Ar} /{ }^{39} \mathrm{Ar}$ & $10-60$ & Laser-GMS $^{\text {d }}$ & geolog. age \\
${ }^{18} \mathrm{O}$ & stable & fractionation & $\delta^{18} \mathrm{O}$ & $-25-+25 \%$ & GMS $^{\mathrm{d}}$ & water origin
\end{tabular}

a accelerator mass spectrometry

${ }^{\mathrm{b}}$ Thermal Ionisation Mass Spectrometry

${ }^{c}$ Multi Cup Inductively Coupled Plasma Mass Spectrometry

${ }^{\mathrm{d}}$ Gas Mass Spectrometry

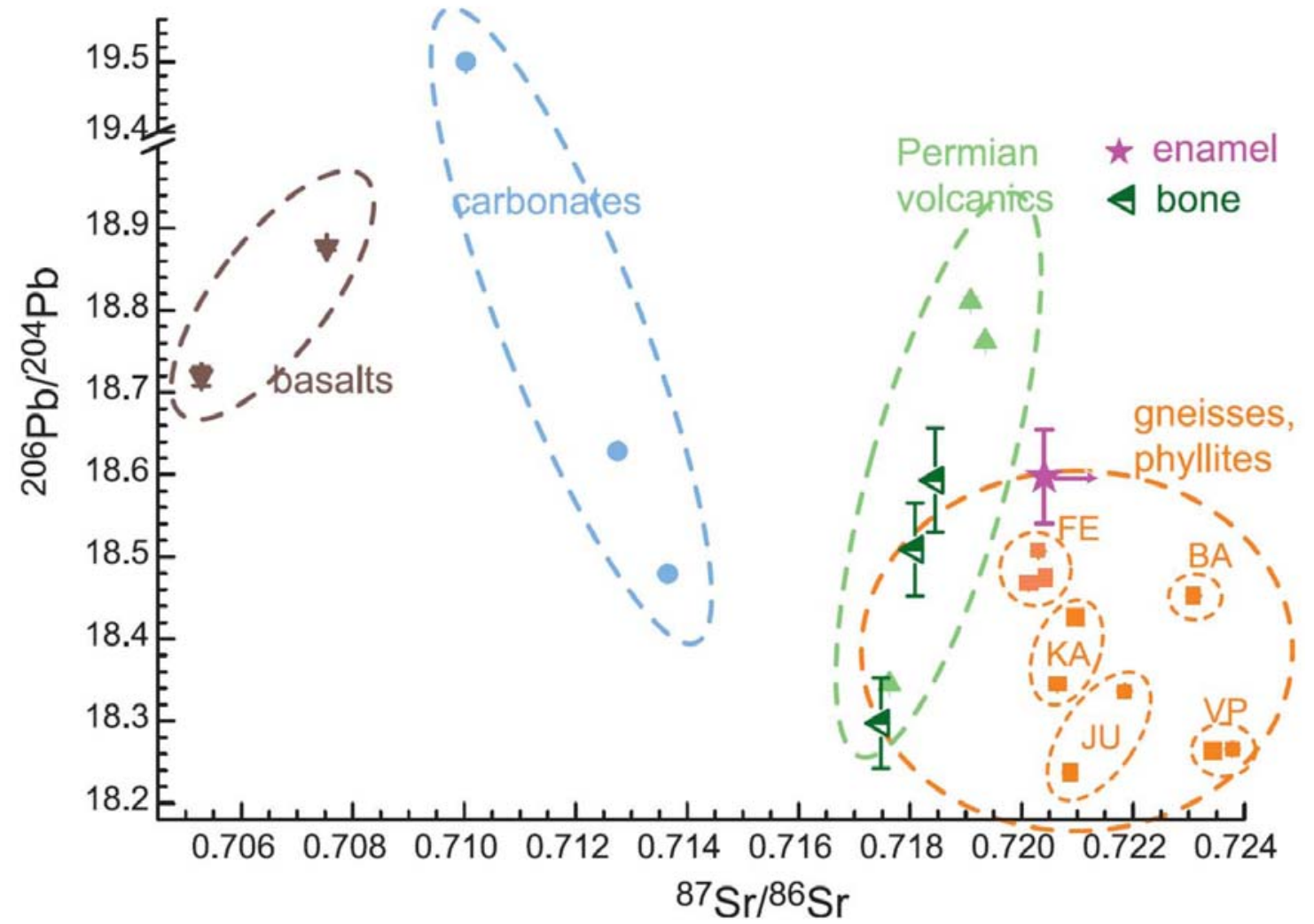

Fig. 3. $\mathrm{Pb}$ versus $\mathrm{Sr}$ isotope data from tooth enamel and bones of the Iceman, together with data from soil leachates from various geological formations in the environment of the Iceman [22]. 
In Fig. 3 the strontium and lead isotope ratios from soils of different geological formations in the environment of the Iceman are plotted together with the values for the teeth and bones. It is obvious that certain geological formations can be excluded. The oxygen isotope ratios measured in the calcium phosphate (apatite) of teeth and bones can be related to the water the iceman was drinking [23]. Since the $\delta^{18} \mathrm{O}$ values on the northern slopes of the European Alps have slightly more negative values that the one from the southern slopes, another isotope signature of the whereabout of the Iceman can be established. In addition, from small mica samples in the intenstine Ar-Ar ages were determined which gave geological ages. Putting all the evidence together, the Eisack valley in South Tyrol (Italy) was established [22] as the most likely place were the Iceman spent his childhood, and most of his later life also south of the main Alpine divide.

\section{The ${ }^{14} \mathrm{C}$ bomb peak dating of human DNA}

It is well known that after the Second World War, the superpowers (USA and USSR) started to test ever bigger nuclear bombs (fission and hydrogen fusion) in the atmosphere. This produced a number of radioisotopes, among them also ${ }^{14} \mathrm{C}$. This happens because nuclear bomb explosions are accompanied by large neutron fluxes, which convert nitrogen into ${ }^{14} \mathrm{C}$ through the ${ }^{14} \mathrm{~N}(\mathrm{n}, \mathrm{p}){ }^{14} \mathrm{C}$ reaction. The very same reaction produces also natural ${ }^{14} \mathrm{C}$, with the neutrons coming from spallation reactions of cosmic ray protons on nuclei of the atmosphere [24]. Atmopsheric nuclear testing continued until 1963, when the Nuclear Test Ban Treaty (NTBT) put an end to atmospheric nuclear weapons testing. By that time the ${ }^{14} \mathrm{C}$ content in atmospheric $\mathrm{CO}_{2}$ was doubled (see Figure 4).

It is interesting to note, that every species living in the second half of the $20^{\text {th }}$ century got labeled with some bomb ${ }^{14} \mathrm{C}$, since ${ }^{14} \mathrm{CO}_{2}$ enters the biosphere through the photosynthesis of plants. Due to the exchange of atmospheric ${ }^{14} \mathrm{CO}_{2}$ with the ocean, the dynamics of this important process can also be studied. In 2005, an interesting paper was published in CELL [25] reporting on the use of the ${ }^{14} \mathrm{C}$ bomb peak to retrospectively determine the birth date of cells in humans. The basic idea is that ${ }^{14} \mathrm{C}$ in genomic DNA reflects the age of the cell. The authors state [25]:

"Most molecules in a cell are in constant flux, with the unique exception of genomic DNA, which is not exchanged after a cell has gone through its last division. The level of ${ }^{14} \mathrm{C}$ integrated into genomic DNA should thus reflect the level in the atmosphere at any given point, and we hypothesized that determination of ${ }^{14} \mathrm{C}$ levels in genomic DNA could be used to retrospectively establish the birth date of cells in the human body.” 

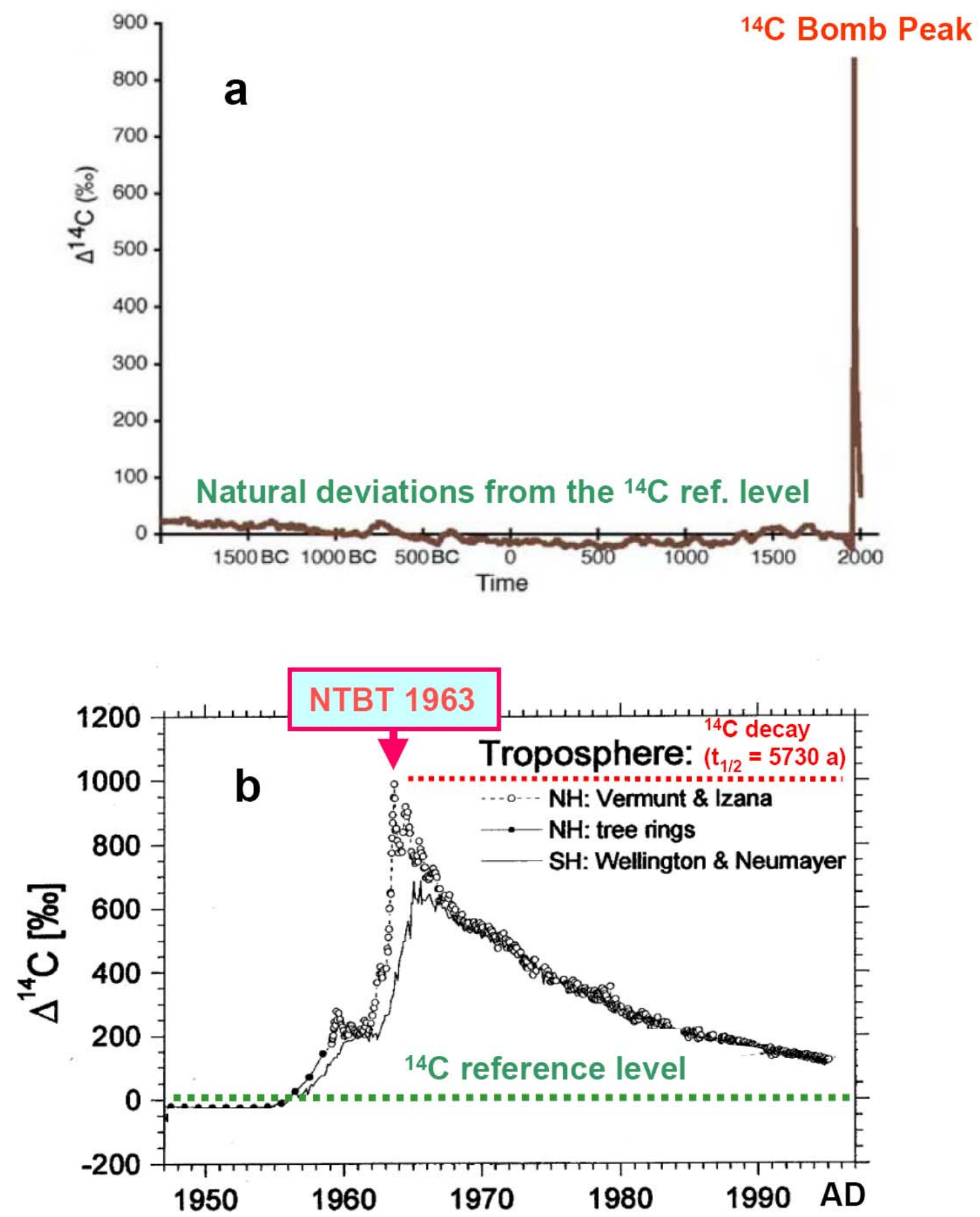

Fig. 4. (a) Variation of the ${ }^{14} \mathrm{C}$ content in atmospheric $\mathrm{CO}_{2}$ during the last 4000 years including the ${ }^{14} \mathrm{C}$ bomb peak [25]. Deviations from the ${ }^{14} \mathrm{C}$ reference level $\left({ }^{14} \mathrm{C} /{ }^{12} \mathrm{C}=1.2 \times 10^{-12}\right)$ are given. (b) Detail of the bomb peak during the last 50 years from measurements of ${ }^{14} \mathrm{C}$ in atmospheric $\mathrm{CO}_{2}$ in the northern and in the southern hemisphere [26]. 
In Table 3 some facts about the DNA molecule are listed, including the calculation from how many cells one has to extract the DNA in order to get enough ${ }^{14} \mathrm{C}$ atoms for an AMS measurement.

Table 3. Composition of the DNA molecule and its ${ }^{14} \mathrm{C}$ content (a physicist's view)

Basic composition of DNA:

Chemical sum formula per bp:

Molecular weight:.

Mass of DNA per cell:

Mass of carbon (40 wt\% C):

Total length of DNA per cell:

$\mathrm{C}$ atoms of DNA per cell:

${ }^{14} \mathrm{C} /{ }^{12} \mathrm{C}$ :

DNA of 10 cells:

15 million cells:

C from DNA of 15 million cells:

Tote 14C AMS detection efficiency:
Macromolecule with $3 \times 10^{9}$ base pairs (bp)

$\mathrm{C}_{20} \mathrm{H}_{23} \mathrm{~N}_{7} \mathrm{O}_{13} \mathrm{P}_{2}$ and $\mathrm{C}_{19} \mathrm{H}_{22} \mathrm{~N}_{8} \mathrm{O}_{13} \mathrm{P}_{2}$

$\sim 630$ Daltons (Da) per base pair, total $\sim 1.9 \times 10^{12} \mathrm{Da}$

2 DNA per cell $=2 \times 3 \mathrm{pg}=6 \mathrm{pg}$

$2.4 \mathrm{pg}$

$2 \times 3 \times 10^{9} \times(0.34 \mathrm{~nm}$, distance between $\mathrm{bp})=2 \mathrm{~m}$

$2 \times 3 \times 10^{9} \times(20 \mathrm{C})=1.2 \times 10^{11} \mathrm{C}$ atoms

$1.2 \times 10^{-12}$

$\sim 1{ }^{14} \mathrm{C}$ atom

1.5 million ${ }^{14} \mathrm{C}$ atoms

$\sim 36 \mu \mathrm{g} \mathrm{C}$

$\sim 2 \% \rightarrow \sim 30,000{ }^{14} \mathrm{C}$ atoms detected

An example of the different times when human cells are formed after a person's birth is shown in Fig. 5.It is obvious from the figure that the ${ }^{14} \mathrm{C}$ content of the DNA from brain cells point to a time much closer to the birthdate than cells from the intestine, which are known to be frequently renewed. As for the brain itself, one can see that cells of the cerebellum are closer to the person's birth date than the one of the cortex. In Fig. 6 a further differentiation into neuronal and non-neoronal cells shows that the cortical neurons are closest to the birth, whereas nonneuronal cells of the cortex point to a substantial production at a later stage in life. In Fig. 6 the brain of four different individuals were investigated, two of them born after the bomb peak (A and $\mathrm{B}$ ), and two before the bomb peak. Due to the very different shape of the curve, additional information about the separation of different brain cells can be studied. The method has been applied by the Stockholm group also for other interesting questions such as the neurogenesis of the human neocortex [27], turnover of fat cells in humans [28], and the renewal of heart cells (cardiomyocites) in humans [29]. 


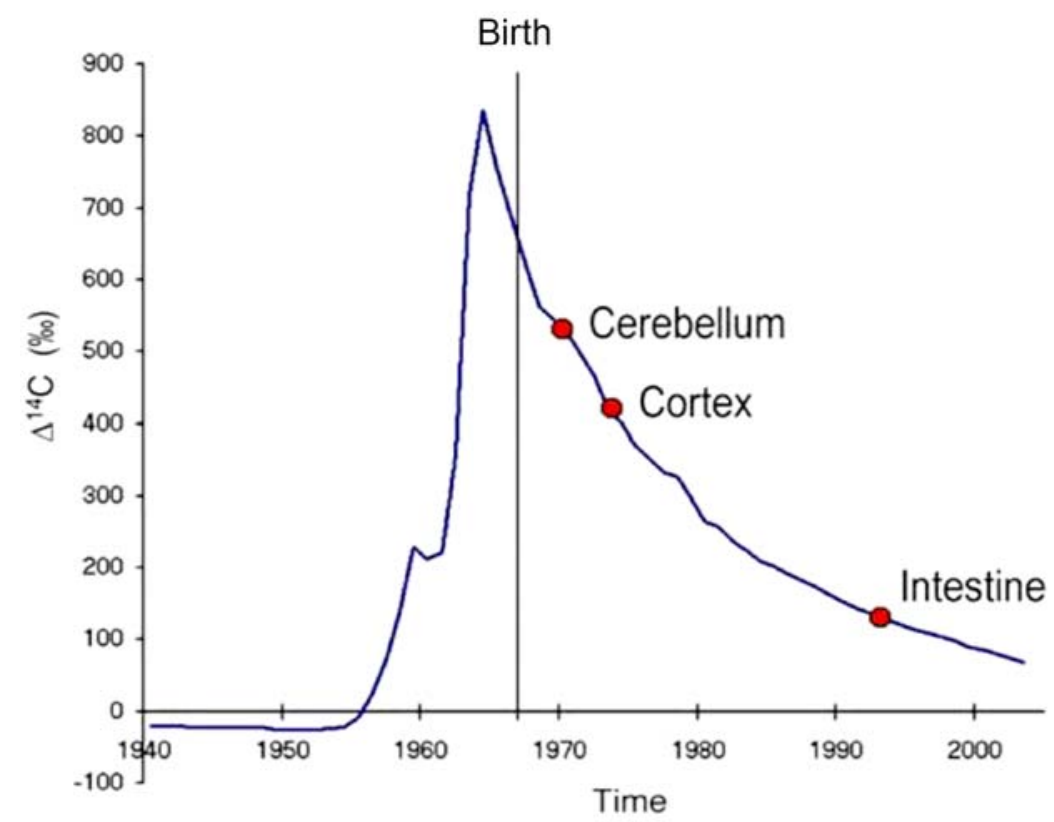

Fig. 5. The ${ }^{14} \mathrm{C}$ content of different human cells indicates the time after birth when the respective cells were formed [25]. The vertical line shows the birth date of the individual.

A
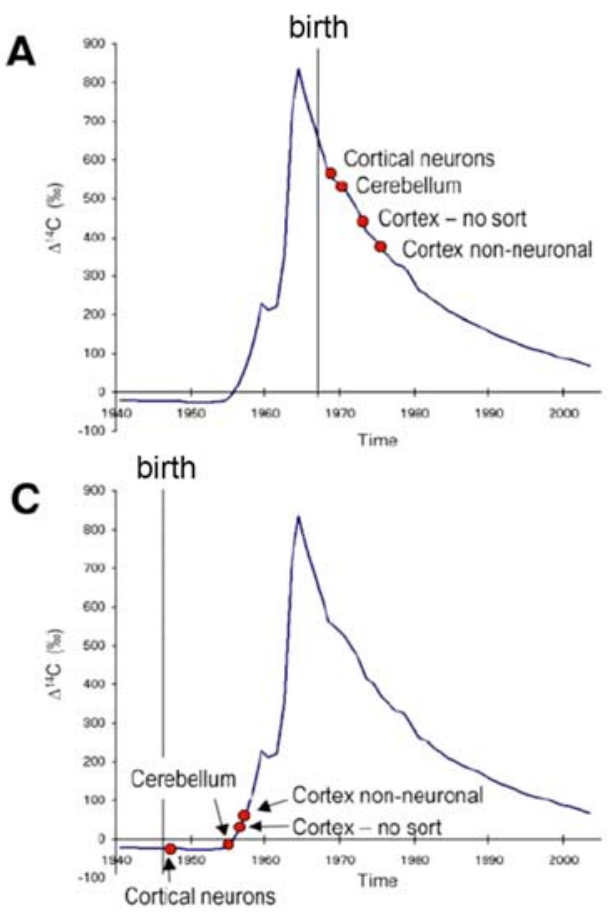

B

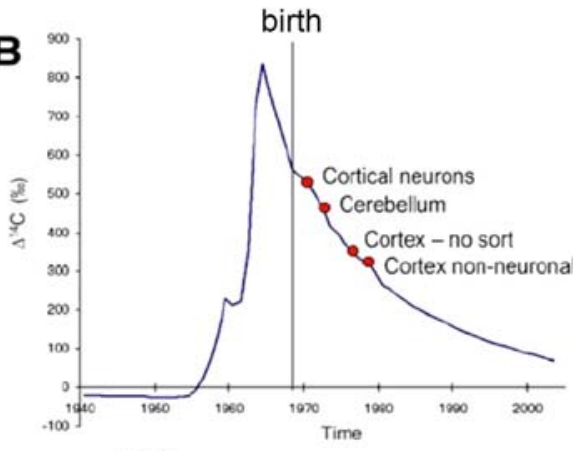

D

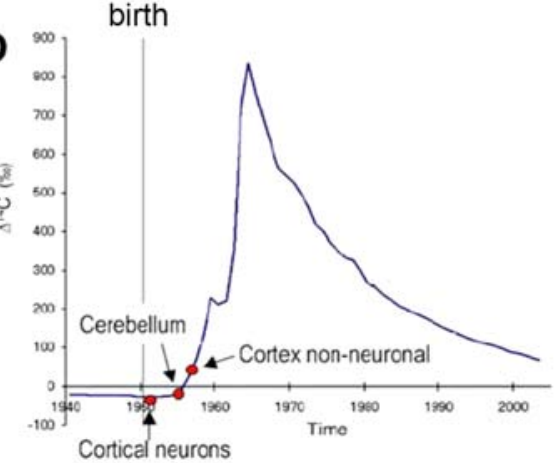

Fig. 6. Separation of neurons from non-neuronal cells show the different times after birth where they were formed [25]. Two individuals (A, B) were born after the bomb peak, and to (C, D) were born before the bomb peak. 


\section{Search for Superheavy Elements in Nature}

Calculating the stability of heavy nuclei has always been a challenge to nuclear theorists. In the 1960s an exciting possibility emerged, when shell-model corrections to the liquid-drop model indicated that there may be a neutron-rich 'island of stability' beyond any known nuclide [30-33]. Nucleosynthesis calculation indicated that such nuclei may be produced under stellar r-process conditions [34]. For the superheavy nucleus with $\mathrm{Z}=110$ and $\mathrm{N}=184$ a half-life of 2.5 billion years was calculated [35]. A specific AMS search for this isotope was therefore performed in 1980 on a platinum nugget [36]. It was assumed that element $Z=110$ has similar chemical properties as platinum. No events of a ${ }^{294} 110$ isotope was observed with an abundance limit of ${ }^{294} 110 / \mathrm{Pt}=1 \times 10^{-11}$. Many other searches for SHEs in natural materials were performed [37, 38]. To this day, no confirmed evidence for long-lived SHEs in nature exist, even though some evidence for the occurrence of neutron-deficient isotopes in thorium [39], and SHEs in gold [40] and thorium [41] have been reported from measurements with ICP-SFMS (Inductively Coupled Sector Field Mass Spectrometry. These extraordinary claims certainly need verification by other experiments before one can accept it as evidence for the existence of SHEs in nature.

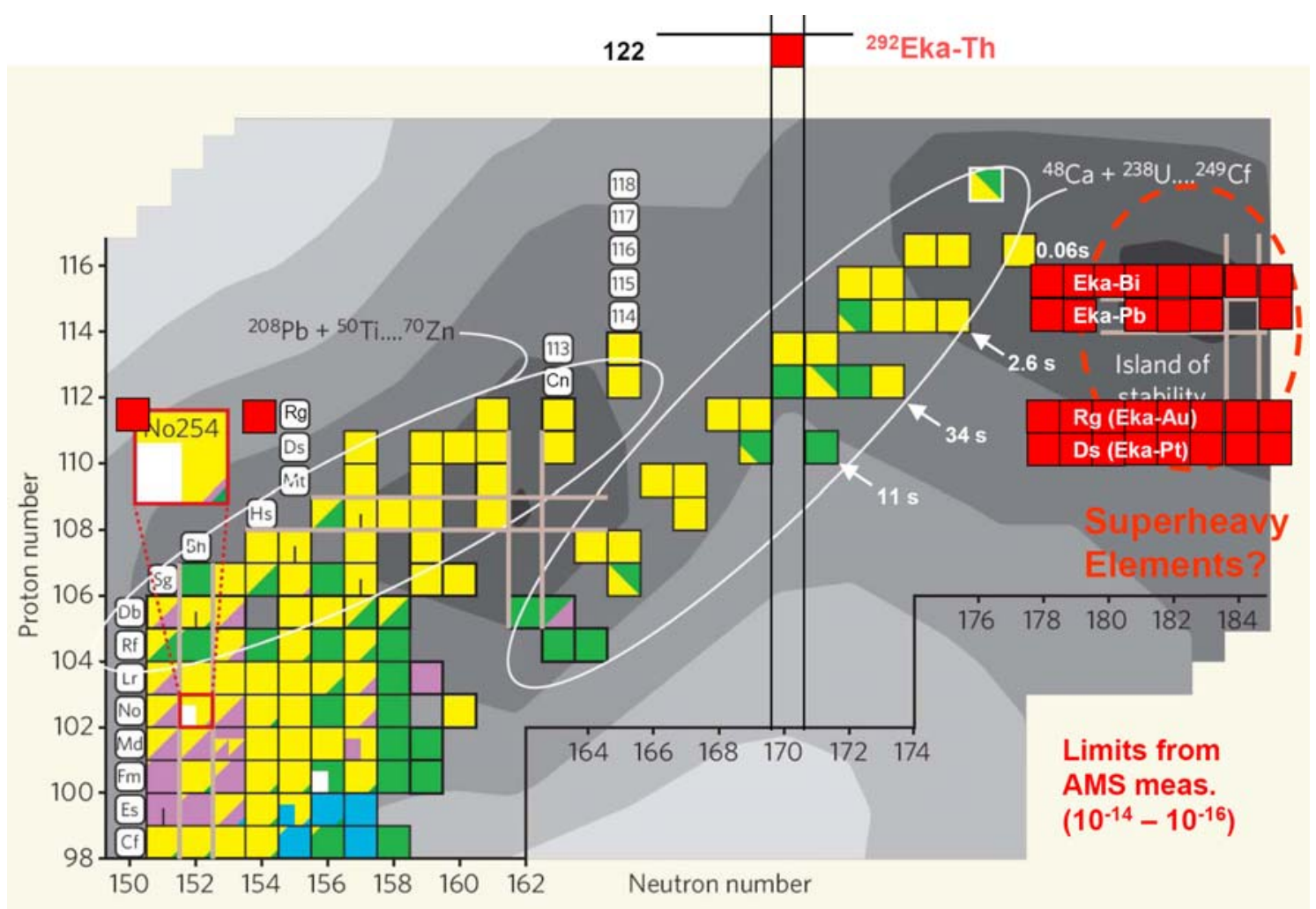

Fig. 7. Upper end of the chart of nuclides indicating the region of increased stability (dark shaded background) where superheavy nuclides are expected to be particularly stable [46]. The basic figure is adopted from Stoyer [42], with the nuclides studied at VERA indicated by red squares. 
It is well known that the 'peak' on the island of stability around $\mathrm{Z}=114$ and $\mathrm{N}=184$ cannot be reached with current heavy-ion reactions. However it was possible to explore the less neutron-rich 'shore' of the island with heavy ion reactions, which established many short-lived isotopes of elements all the way up to $Z=118[42,43]$. In order to check the claims for SHE observation at natural abundances by the group of Marinov et al. [39-41], we have embarked at VERA on an extensive SHE search using AMS. This allows one to identify possible SHE events more stringently than is possible with ICP-SFMS. So far, we have set limits for thorium isotopes, which are about 3 orders of magnitude lower [44] than the one reported in [38, 40]. With somewhat less sensitivity, the Munich AMS group did also not confirm the evidence for neutron-deficient thorium isotopes [45].

In Fig. 7 the regions of superheavy nuclides which are investigated at VERA are shown. Except for the results published by Dellinger et al. on the thorium isotopes [44], the limits set for the nuclides marked in red have to be considered as preliminary [47]. As can be seen, we try to cover with our search the centre of the island of stability. We use natural materials with the assumption that the corresponding eka-elements follow the corresponding elements, although due to relativistic effects this may not be necessarily the case [48, 49]. Materials investigated so far include Platinum nuggets (Eka-Pt, $Z=110$, Ds), Gold nuggets (Eka.Au, $Z=111$, Ds), Galenite - PbS (Eka-Pb, Z = 114), Bismuth ochre $-\mathrm{Bi}_{2} \mathrm{O}_{3}$ (Eka-Bi, $\mathrm{Z}=115$ ), and Thorianite $\mathrm{ThO}_{2}$ (Eka-Th, $\mathrm{Z}=122$ ). So far we have not found a candidate for a SHE nuclide in the indicated region at abundance levels in the range of $10^{-14}$ to $10^{-16}$, but the search goes on ...

\section{Conclusion}

The examples discussed in this review were chosen in order to convey the power of reading the isotope language in a variety of different applications. Since mass spectrometric methods - both with and without accelerators - are continuously refined, it is likely that new ground will be broken in future. It is hoped that reading and interpreting the isotope language will help to disentangle some of the complex processes influencing our climate on Earth. Isotope studies will also naturally cross disciplines, which will help to promote 'integrated' research - in some cases even beyond fields of natural sciences extending into the realm of the humanities.

\section{Acknowledgement}

Discussions on the superheavy element studies at VERA with Franz Dellinger are gratefully acknowledged. 


\section{References}

[1] F. Soddy, Intra-atomic charge, Nature 92 (1913) 399.

[2] J. J. Thomson, Bakerian Lecture: Rays of Positive Electricity, Proc. Roy. Soc. A 89 (1913) 1.

[3] J. Chadwick, The Existence of a Neutron, Proc. Roy. Soc. A 136 (1932) 692.

[4] W. Kutschera, Progress in isotope analysis at ultra-trace level by AMS, Int. J. Mass Spectrom. 242 (2005) 145.

[5] T. Walczyk, F. von Blanckenburg, Natural Iron Variation in Human Blood, Science 295 (2002) 2065.

[6] A. N. Halliday, D-C. Lee, Tungsten isotopes and the early development of the Earth and Moon, Geochim. Cosmochim. Acta 63 (1999) 4157.

[7] E .M. Wild, S. Guillen, W. Kutschera, H. Seidler, P. Steier, Radiocarbon dating of the Peruvian Chachaboya/Inka site at the Laguna de los Condores, Nucl. Instr. and Meth. B 259 (2007) 378.

[8] M .J. Scheoninger, M. J. DeNiro, Nitrogen and carbon isotopic composition of bone collagen from marine and terrestrial animals, Geochim. Cosmochim. Acta 48 (1984) 625.

[9] M. P. Richards, P. B. Pettitt, E. Trinkhaus, F. H. Smith, M. Paunovic, I. Karavanic, Neanderthal diet at Vindija and Neanderthal predation: The evidence from stable isotopes, Proc. Nat. Acad. Sci. 97 (2000) 7663.

[10] W. Kutschera, AMS and climate change, Nucl. Instr. and Meth. B 268 (2010) 693.

[11] North Greenland Ice Core Project members, High-resolution record of Northern Hemisphere climate extending in to the last interglacial period, Nature 431 (2004) 147.

[12] J. R. Petit et al., Climate and atmospheric history of the past 420,000 years from the Vostok ice core, Antarctica, Nature 399 (1999) 429.

[13] EPICA community members, Eight glacial cycles from an Antarctic ice core, Nature 429 (2004) 623.

[14] F. C. Bassinot et al., The astronomical theory of climate and the age of the Brunhes-Matuyama magnetic reversal, Earth Planet. Sci. Lett. 126 (1994) 91.

[15] M. Milankovic, Kanon der Erdbestrahlungen und seine Anwendung auf das Eiszeitproblem, Serb. Akad. Belgrad (1941) 484.

[16] J. D. Hays, J. Imbrie, N. J. Shackleton, Variations in the Earth's orbit: pacemaker of the Ice Ages, Science 194 (1976) 1121.

[17] A. Berger, The Milankovitch astronomical theory of paleoclimates: a modern review, Vistas in Astronomy 24 (1980) 103.

[18] W. S. Broecker and G. H. Denton, What drives glacial cycles, Sci. Amer. (January 1990) 43. 
[19] R. E. M. Hedges, R. A. Housley, C. R. Bronk, G. J. van Klinken, Radiocarbon dates from the Oxford AMS system: Archaeometry datelist 15, Archaeometry 34 /2 (1992) 337.

[20] G. Bonani, S. D. Ivy, I. Hajdas, T. R. Niklaus, M. Suter, $A M S{ }^{14} C$ age determination of tissue, bone and grass samples from the Ötztal Ice Man, Radiocarbon 36/2 (1994) 247.

[21] W. Kutschera, W. Müller, "Isotope language" of the Alpine Iceman investigated with AMS and MS, Nucl. Instr. and Meth. B 204 (2003) 705.

[22] W. Müller, H. Fricke, A. N. Halliday, M. T. McCulloch, J.-A. Wartho, Origin and migration of the Alpine Iceman, Science 302 (2003) 862.

[23] A. Longinelli, Oxygen isotopes in mammal bone phosphate: A new tool for paleohydrological and paleoclimatological research?, Geochim. Cosmochim. Acta 48 (1984) 385.

[24] E. C. Anderson, W. F. Libby, S. Weinhouse, A. F. Reid, A. D. Kirshenbaum, A. V. Grosse, Natural radiocarbon from cosmic radiation, Phys. Rev. 72 (1947) 931.

[25] K. L. Spalding, R. D. Bhardwaj, B. A. Buchholz, H. Druid, J. Frisén, Restrospective birth dating of cells in humans, Cell 122 (2005) 133.

[26] I. Levin, V. Hesshaimer, Radiocarbon - a unique tracer of global carbon cycle dynamics, Radiocarbon 42/1 (2000) 69.

[27] R. D. Bhardwaj et al., Neocortical neurogenesis in humans is restricted to development, Proc. Nat. Acad. Sci. 103 (2006) 12564.

[28] K. L. Spalding et al., Dynamics of fat cell turnover in humans, Nature 453 (2008) 783.

[29] O. Bergman et al., Evidence for cardiomyocyte renewal in humans, Science 324 (2009) 98.

[30] W. D. Myers, W. J. Swiatecki, Nuclear masses and deformations, Nucl. Phys. 81 (1966) 1.

[31] V. M. Strutinsky, Shells in deformed nuclei, Nucl. Phys. A 122 (1968) 1.

[32] S. G. Nilsson et al., On the spontaneous fission of nuclei with Z near 114 and N near 184, Nucl. Phys. A 115 (1968) 545.

[33] S. G. Nilsson et al., On the nuclear structure and stability of heavy and superheavy elements, Nucl. Phys. A 131 (1969) 1.

[34] D. N. Schramm, W. A. Fowler, Synthesis of superheavy elements in the e-process, Nature 231 (1971) 103.

[35] E. O. Fiset, J. R. Nix, Calculation of half-lives for superheavy nuclei, Nucl. Phys. A 193 (1972) 674.

[36] W. Stephens, J. Klein, R. Zurmühle, Search for naturally occurring superheavy element Z = 110, A = 294, Phys. Rev. C 21 (1980) 1664.

[37] G. Herrmann, Superheavy-element research, Nature 280 (1979) 543.

[38] G. N. Flerov, G. M. Ter-Akopian, Superheavy nuclei, Rep. Prog. Phys. 46 (1983) 817.

[39] A. Marinov, I. Rodushkin, Y. Kashiv, L. Halicz, I. Segal, A. Pape, R. V. Gentry, H. W. Miller, D. Kolb, R. Brandt, Existence of long-lived isomeric states in naturally-occurring neutron-deficient Th isotopes, Phys. Rev. C 76 (2007) 021303 (R). 
[40] A. Marinov, I. Rodushkin, A. Pape, Y. Kashiv, D. Kolb, R. Brandt, R. V. Gentry, H. W. Miller, L. Halicz, I. Segal, Existence of long-lived isotopes of a superheavy element in natural Au, Int. J. Mod. Phys. E 18 (2009) 621.

[41] A. Marinov, I. Rodushkin, D. Kolb, A. Pape, Y. Kashiv, R. Brandt, R. V. Gentry, H. W. Miller, Evidence for the possible existence of a long-lived superheavy nucleus with atomic mass number $A$ = 292 and atomic number Z 122 in natural Th, Int. J. Mod. Phys. E 19 (2010) 131.

[42] M.A. Stoyer, Island ahoy!, Nature 442 (2006) 876.

[43] S. Hofmann, Exploring the island of superheavy elements, Physics 3 (2010) 31.

[44] F. Dellinger, O. Forstner, R. Golser, W. Kutschera, A. Priller, P. Steier, A. Wallner, G. Winkler, Search for a superheavy nuclide with $A=292$ and neutron-deficient thorium isotopes in natural thorianite, Nucl. Instr. and Meth. B 268 (2010) 1287.

[45] L. Lachner, I. Dillmann, T. Faestermann, G. Korschinek, M. Poutivtsev, G. Rugel, Search for longlived isomeric states in neutron-deficient thorium isotopes, Phys. Rev. C 78 (2008) 064313.

[46] A. Sobiczewski, K. Pomorski, Description of structure and properties of superheavy nuclei, Prog. Part. Nucl. Phys. 58 (2007) 292.

[47] F. Dellinger, PhD thesis, University of Vienna, in preparation.

[48] E. Eliav, U. Kaldor, P. Schwerdtfeger, B. A. Hess, Y. Ishakawa, Ground state configuration of element 111, Phys. Rev. Lett. 73 (1994) 3203.

[49] R. Eichler et al., Chemical characterization of element 112, Nature 447 (2007) 72. 